Murata K., Tezel A., Koskela L., and Tzortzopoulos P. (2018). "Sourcesof Waste on Construction Worksite:A Comparisonto the Manufacturing Industry." In: Proc. $26^{\text {th }}$ Annual Conference of the International. Group for Lean Construction (IGLC), González, V.A. (ed.), Chennai, India, pp. 973-981. DOI: doi.org/10.24928/2018/0280. Available at: <www.iglc.net>.

\title{
SOURCES OF WASTE ON CONSTRUCTION SITE: A COMPARISON TO THE MANUFACTURING INDUSTRY
}

\author{
Koichi Murata ${ }^{1}$, Algan Tezel ${ }^{2}$, Lauri Koskela ${ }^{3}$, and Patricia Tzortzopoulos ${ }^{4}$
}

\begin{abstract}
The wastes of the supply chain should be reduced to achieve the stabilization of construction operations in lean-based construction management. The aim of this paper is to investigate the communication related sources of waste on construction worksite when compared to the manufacturing industry. The methodology used involves several observations of Japanese construction worksites and interviews with worksite managers and executives of some construction companies, and public institutions, and participation at forums for exchanging practical construction experiences conducted over the last few years. Two main results are obtained. The first one details the three peculiarities of construction, specific customer, site production, and temporary organization as described in prior research. The second one proposes a structural model to depict wastes caused by temporary organization, one of the three mentioned peculiarities. These findings contribute to better understanding of the peculiarities of construction in view of applying lean techniques, and to broadening the practitioners' viewpoint by providing a guideline to gain the capability of a sharp and systematic understanding of their worksite.
\end{abstract}

\section{KEYWORDS}

Lean construction, waste of production flow, waste of organization

\section{INTRODUCTION}

The key behaviour underpinning successful lean management involves the exploration of waste hidden in a production system. The performance of a production system will be strengthen by eliminating wastes through continuous improvement. This paper

Associate Professor, College of Industrial Technology, Nihon University, Chiba, JAPAN, murata.kouichi30@nihon-u.ac.jp

2 Lecturer, School of Art, Design and Architecture, University of Huddersfield, Huddersfield, UK, A.Tezel@hud.ac.uk

3 Professor of Construction and Project Management, University of Huddersfield, Huddersfield, UK, L.Koskela@hud.ac.uk

4 Professor, School of Art, Design and Architecture, University of Huddersfield, Huddersfield, UK, P.Tzortzopoulos@hud.ac.uk 
investigates, from a lean viewpoint, the source of waste occurring on construction worksite. As the starting point, two perspectives are adapted to discuss the issue: (1) the wastes in operations at construction worksites and (2) the organizational wastes caused by the constraints of place and time, peculiar to the construction industry.

This paper endeavours to contribute to the systematization of waste elimination for the construction industry. Related previous publications have concentrated on wastes of just one production flow to improve construction production systems by industrial engineering approach (dos Santos 1999). This paper aims to present a more general theory of common waste hidden in construction production systems.

In general, practitioners have valuable practical insights to the subject. The important role of academia on the theory of lean management concerns with providing support to broaden the practitioners' viewpoint by offering guidelines for them to gain the capability of accurate and systematic understanding of their worksite.

In Toyota Motor Corporation, where lean thinking first emerged, seven wastes have been proposed, based on automobile production (discrete manufacturing) (Ohno 1988). This taxonomy continues to be a very useful approach considering the production management generally. In the area of industrial engineering, Therbligs established basic motion elements to add a value to management resources through analysing manual operations (Gilbreth 1915). Recently, the meaning of waste was explored in a literature review (Thürer 2017). These forerunners contributed to clarify the classification of wastes existing in a production system.

It is well known that massive operational wastes exist on construction worksites (Koskela 1992; 2002). There are many publications on wastes under lean construction. Researchers and consultants have mainly reviewed the seven wastes, and analysed them from the viewpoint of construction projects (Alarcón 1997; Fearne 2006; Mandujano 2017; Sarhan 2013; 2017; Somani 2017; Serpell 1995). Koskela (2004) has also proposed 'making-do', as the eighth category of waste, which refers to a situation where a task is started without all its standard inputs, or the execution of a task is continued although the availability of at least one standard input has ceased. Macomber (2004) also indicates 'the two great wastes', not listening and not speaking, which relate to organizations managing the production flow.

This paper focuses on the four peculiarities of the construction industry in relation to elimination of wastes. These peculiarities are reviewed as follows, based on (Koskela 2013):

- Specific customer. The idea of overproduction as the most important waste is conceptually and experientially not consistent with one-of-a-kind production. Construction is usually a produce-to-order process. This is in contrast with the situation in mass production, where it can be necessary or tempting to produce before there is a customer order. From experience, we know that construction projects get completed more often after the due date than before it. If there is the possibility of completing before the planned due date, it may be possible to take the facility into use earlier. All in all, the claim of overproduction as the most important waste of construction cannot be justified. 
- Design stage. Although the seven wastes can largely be interpreted as applying also to design, there may be aspects in design that are not covered. Thus, for example, the failure to achieve the best possible solution in design, certainly a waste for the customer, is not pinpointed.

- Site production. In manufacturing we find three types of transportation: The transportation of resources to the location of production, internal transportation of the incomplete / intermediate product in production and transportation of the complete product to the customer. The first type of transportation occurs also in construction, the two last not. In site production, it is the teams and equipment that move around the product. Thus, intermediate (or complete) products do not move at all, whereas workers will by necessity move around the site. However, in our estimation, these differences can be taken care of by a suitable slight redefinition of the waste of movement.

- Temporary organization. This characteristic may lead to think about the vagaries of communication and requests and promises between parties previously unknown to each other. The language/action perspective has been used to analyze such a setting in construction (Azambuja 2006). However, there we may be dealing, not with wastes as such, but primarily with the causes of waste.

Especially, this paper involves the following two discussions to understand the above three peculiarities of the four (except design stage) because the investigation of this paper is mainly focused on construction worksites. The first one involves the survey of the details of the three peculiarities, specific customer, site production, and temporary organization, which relate to wastes in production process. The second one proposes a structural model of causation of wastes by a temporary organization.

Four contributions are expected in this paper. Firstly, the seven wastes are deeply discuss for construction. Secondly, an original approach to eliminate wastes for the construction industry will be developed by understanding the details of each peculiarity as the starting point of the problem-solving. Thirdly, it becomes easy to connect the wastes to the lean toolbox, to detect and eliminate wastes through visual management, karakuri, poka-yoke and so on (Murata 2010; 2013). Fourthly, practitioners can concretely visualize the sources of wastes.

The methodology of the following discussions is based on several observations of Japanese construction worksites, interviews with worksite managers and executives of some construction companies and a public institution, and on participations at forums for exchanging practical construction experiences, conducted over the last few years. These events have been arranged by organizations located in Tokyo and adjacent prefectures, having an interest in the TPS for improving construction worksites. The lead author has implemented and studied lean management in the manufacturing industry for a long time. His investigation approach is the inductive method to demonstrate and clarify the difference of the implementation of lean management between the construction industry and the manufacturing industry. This paper reports an initial result of the analysis. 


\section{BASIS OF OPERATION WASTE ON CONSTUCTION SITE}

This section describes the results from investigating peculiarities of the construction worksite, comparing the construction industry to the manufacturing industry.

A product of the construction industry, such as a building or a house, is produced on a construction worksite. Once materials are delivered to the site, they don't go outside and only wait to be consumed. After completing the project, a constructor needs to hand over the finished product to users in the same place as the construction worksite. Therefore, it is necessary not only to ensure the product's quality but also to develop the living environment for users of the product during the construction process at the same time. These conditions are considered as the different points of supply chain management to control management factors, compared with operations within the factory environment, which provides finished products to the market that is accessed by end users.

The size of the managed resources, including materials and machines/equipment/ facilities on a construction site is much larger than that of the manufacturing industry. Actually, depending on the nature of tasks, construction professionals may track the progress of a project by calculating the amount of materials/components installed or constructed. However, the same control is executed by the number of finished products in case of a factory. The same production lead time approach as in the manufacturing industry can be used in the construction industry by diving larger tasks (ie., building or floor) into smaller work chunks or even into smaller areas (location based planning and control). Such a difference caused by the physical and temporal scales of management resources brings the result that a reliable picture of the whole of production and progress against plan cannot be confirmed at a glance.

In addition, regarding the variability reduction principle for increased quality and productivity, many repeated operations are included in the mass-production system that caters to mass-consumption.

Table 1 summarises the above differences in the attributes of a production system between the two industries, in reference to the three peculiarities. These indicate that it is difficult to directly apply lean methods from the manufacturing industry to the construction industry, and that it is necessary to develop the theory of lean construction though studying construction worksites' operations.

\section{FOUR BOUNDARIES THAT OBSTRUCT COMMUNICATION}

This section focuses on temporary organization, one of the peculiarities for construction. While carrying out research on the organizational problem-solving scheme on construction worksites, based on experience in manufacturing industry, it was observed that there were two clear differences in communication among worksite members when compared to the communication in the manufacturing industry (Murata 2015; 2017).

First, construction projects that have different specifications are executed at the same time and in different locations. Second, although many different specialists join one project, they can't witness the completion of the project together. The former causes a geographical boundary and the latter draws out a temporal boundary for communication 
among company members. In addition, this two-boundary structure has other structures nesting inside it.

Table 1: Difference of the attributes of a production system between manufacturing and construction, with reference to construction peculiarities

\begin{tabular}{|c|c|c|c|c|}
\hline \multicolumn{2}{|c|}{ Attributes of production system } & \multirow{2}{*}{$\begin{array}{c}\begin{array}{c}\text { Manufacturing } \\
\text { industry }\end{array} \\
\text { Mass products }\end{array}$} & \multirow{2}{*}{$\begin{array}{c}\begin{array}{c}\text { Construction } \\
\text { industry }\end{array} \\
\text { Same } \\
\text { structures } \\
\text { built in one } \\
\text { product }\end{array}$} & \multirow{2}{*}{$\begin{array}{c}\begin{array}{c}\text { Peculiarities of } \\
\text { construction } \\
\text { worksite (Koskela } \\
\text { 2013) }\end{array} \\
\text { Specific customer }\end{array}$} \\
\hline Operations & $\begin{array}{l}\text { Repeated } \\
\text { operations }\end{array}$ & & & \\
\hline \multirow[t]{2}{*}{$\begin{array}{l}\text { Product and } \\
\text { supply chain }\end{array}$} & $\begin{array}{l}\text { Flow of martials } \\
\text { and finished } \\
\text { product }\end{array}$ & $\begin{array}{c}\text { Supplier- } \\
\text { Factory-Market }\end{array}$ & $\begin{array}{l}\text { Supplier- } \\
\text { Construction } \\
\text { site }\end{array}$ & Specific customer \\
\hline & $\begin{array}{c}\text { Places of } \\
\text { production and } \\
\text { utilization of } \\
\text { finished product }\end{array}$ & Different & Same & Site production \\
\hline \multirow[t]{3}{*}{$\begin{array}{l}\text { Management } \\
\text { resources } \\
\text { (Physical and } \\
\text { temporal } \\
\text { scales) }\end{array}$} & $\begin{array}{l}\text { Size of managed } \\
\text { objects (martials, } \\
\text { machines/ } \\
\text { equipment/ } \\
\text { facilities) }\end{array}$ & Small & Large & Site production \\
\hline & $\begin{array}{l}\text { Production lead- } \\
\text { time }\end{array}$ & $\begin{array}{l}\text { Short (Daily, In } \\
\text { minutes or, } \\
\text { Seconds) }\end{array}$ & $\begin{array}{l}\text { Long } \\
\text { (Yearly or } \\
\text { Monthly) }\end{array}$ & Site production \\
\hline & Participants & Same members & $\begin{array}{c}\text { Different } \\
\text { specialists }\end{array}$ & $\begin{array}{l}\text { Temporary } \\
\text { organization }\end{array}$ \\
\hline
\end{tabular}

Each structure involves each worksite of each project at present. The characteristics of this communication in the construction industry is shown in Figure 1.

Generally, information sharing among worksite members involves the important process of reliable and successful problem solving. However, a construction site including this structure, which disturbs communication among project members, is shown in Figure 1. The structure consists of the following four sub-boundaries of the twoboundary structure that are prone to lead to a communication loss:

- Boundary between today's you and tomorrow's you (imagine 'you' as one member on worksite at present)

- Boundary between the head office and a worksite 
- Boundary among members of different teams

- Boundary among projects in different locations

The first and third boundary are the sub-boundaries of the temporal boundary. The second and fourth boundary are the sub-boundaries of the geographical boundary. The first to third boundary concern the execution of a construction plan within one worksite.

The first, second, and fourth boundary can also be found in the manufacturing industry. For example, same people operate together every day in the same factory.

Regarding the first boundary, information sharing among those people is realized in their workplace every day to reduce the variation in management of resources such machines operated and materials used.

For the second boundary, in the overall competition environment, the geographical distribution of factory networks brings that the information of operation status of each one has to be gathered and analysed to receive quick support from the head office.

The fourth boundary relates to the advanced information sharing including technology transfer and knowledge management. Even if all factories manufacture different products, the exchange of valuable experiences with each other ought to be recognized as valuable opportunities to innovate for production system performance.

The third boundary is the special obstruction factor of the construction industry when compared to the manufacturing industry, where the same people work every day together. A construction project is realized by many different specialists such as architects, surveyors, plasterers, carpenters, and plumbers. They join together in one project, however they don't work continuously together from the start to the finish of a project. The situation disturbs the accurate delivery of information of plan progress to the next participants. The main countermeasure for the problem rests on their understanding based on both their experiences from past projects and continuously ensuring the existence of process transparency through information sharing in a project. Overcoming this boundary will be more important to proceed with a production plan on construction worksites.

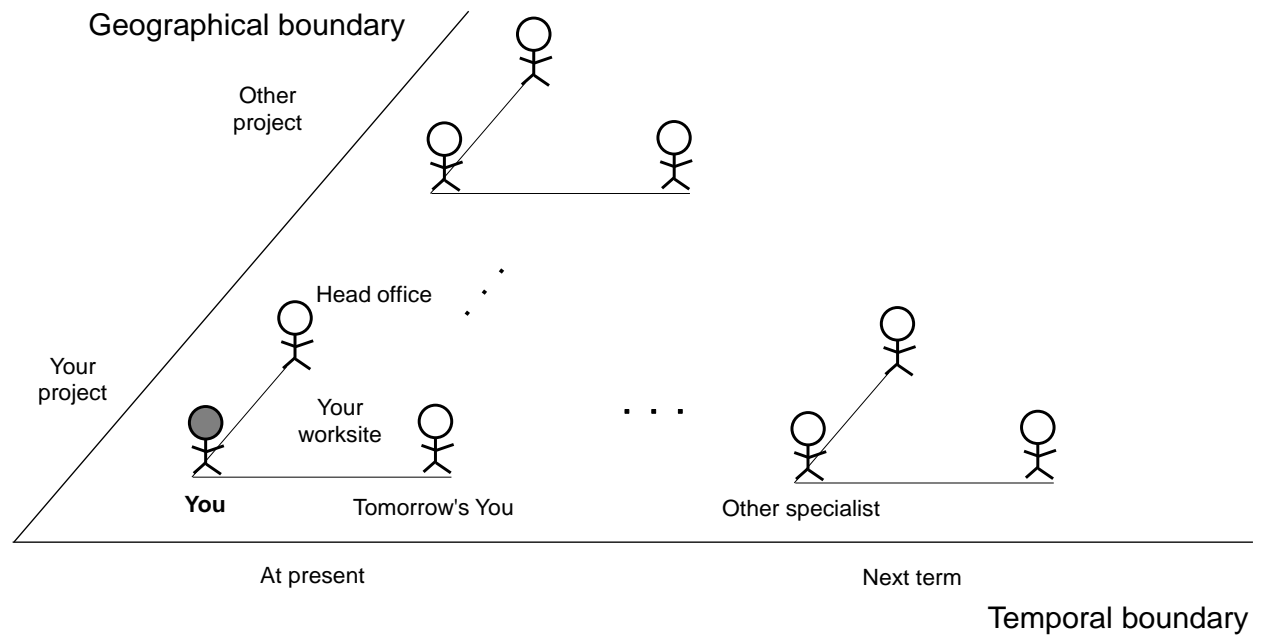

Figure 1: Nested structure model of communication in the construction industry 


\section{CONCLUDING REMARKS}

This paper discussed the sources of waste on construction worksite with the aim of strengthening the theory of lean management in the construction industry by comparing it to the manufacturing industry. It is a finding of this paper that there are two kinds of waste in construction:

- Organizational waste due to lack of connection due to temporal and geographical boundaries

- Operational wastes, hidden in construction production systems

Such two types of waste will be recognized as the implication of the special structure of worksite operations executed within temporal and geographical boundaries in the construction industry. The causes of each one are clearly different. The cause of the first waste is associated with communication among different specialists. The cause of the second waste is associated with management of resources and operations on worksites. In other words, the former is the issue of the design of communication scheme and the latter is about the contents of communication. Lumping them together can possibly be misleading, because the core object of waste reduction in traditional lean management is the second one. This means that it is necessary to establish a scheme to overcome the first one, before eliminating the second one.

The offered perspectives on the lean management theory, and the academic results of this paper are expected to contribute to broadening the practitioners' capability of a sharp and systematic understanding of their worksite.

In future studies, the clarified wastes have to be linked with a lean counter-measure, to minimise their effects on construction production systems. The investigation and systematization of visual management, as part of the related lean toolbox, has recently been on the rise in the lean construction community (Murata 2015; 2016; 2017; Tezel 2016; 2017; Valente 2017). In the next step, the relationship between the wastes and visual management should be developed to realize an original systematic approach to problem-solving for lean construction management.

\section{ACKNOWLEDGEMENT}

This paper was also supported by JSPS KAKENHI Grant Number JP 16 K03897.

\section{REFERENCES}

Alarcón, L. F. (1997). "Modeling Waste and Performance in Construction", Lean Construction, 51-66.

Azambuja, M.M.B. , Isatto, E.L. , Marder, T.S. \& Formoso, C.T. (2006).“The Importance of Commitments Management to the Integration of Make-to- Order Supply Chains in Construction Industry", Proceedings of 14th Annual Conference of the International Group for Lean Construction,609-623, Santiago, Chile.

Dos Santos, A., Powell, J., \& Formoso, C. T. (1999). "Evaluation of Current Use of Production Management Principles in Construction Practice", Proceedings of 7th 
Annual Conference of the International Group for Lean Construction, 73-84, University of California, Berkeley, CA, USA.

Fearne, A., \& Fowler, N. (2006). "Efficiency Versus Effectiveness in Construction Supply Chains: the Dangers of "Lean" Thinking in Isolation", Supply Chain Management: An International Journal, 11(4), 283-287.

Gilbreth, F. B. (1915). "Motion Study for the Crippled Soldier", Journal of the American Society of Mechanical Engineers, 671, 669-673.

Koskela, L. (1992). Application of the New Production Philosophy to Construction(Vol. 72). Stanford, CA: Stanford University.

Koskela, L., Howell, G., Ballard, G., \& Tommelein, I. (2002). "The Foundations of Lean Construction", Design and Construction: Building in Value, 211-226.

Koskela, L. (2004). "Making-Do -the Eighth Category of Waste" Proceedings of 12th Annual Conference of the International Group for Lean Construction, 10 pages, Helsingør, Denmark.

Koskela, L. , Bølviken, T. \& Rooke, J. (2013). "Which Are the Wastes of Construction?”, Proceedings of 21th Annual Conference of the International Group for Lean Construction, 3-12., Fortaleza, Brazil.

Thürer, M., Tomašević, I., \& Stevenson, M. (2017). “On the Meaning of 'Waste': Review and Definition", Production Planning \& Control, 28(3), 244-255.

Macomber, H. \& Howell, G. (2004). "The Two Great Wastes in Organizations", Proceedings of 12th Annual Conference of the International Group for Lean Construction, 9 pages, Helsingør, Denmark.

Mandujano, M. G., Alarcón, L. F., Kunz, J., \& Mourgues, C. (2017). “Identifying Waste in Virtual Design and Construction Practice from a Lean Thinking Perspective: A meta-analysis of the literature, Journal of Construction, 15(3), 107-118.

Murata, K., Tezel, A., Koskela, L., \& Tzortzopoulos, P., (2017). "An Application of Control Theory to Visual Management for Organizational Communication in Construction." LC3 2017 Volume II - Proceedings of the 25th Annual Conference of the International Group for Lean Construction (IGLC), Walsh, K., Sacks, R., Brilakis, I. (eds.), 185-191. DOI: Heraklion, Greece, 9th-12th July.

Murata, K. \& Katayama, H., (2016). "Performance Evaluation of a Visual Management System for Effective Case Transfer", International Journal of Production Research (IJPR), 54(10) 2907-2921.

Murata, K., Nakajima, K., Kinoshita, K., Tezel, A., Koskela, L., Tzortzopoulos, P., \& Katayama, H., (2015). "Investigation of Visual Management Cases in Construction by An Analytical Framework from Manufacturing", Proceedings of 45th International Conference on Computers \& Industrial Engineering (CIE45), 744-751, Université de Lorraine, Metz, France, 28th -30th October.

Murata, K. \& Katayama, H., (2013). "A Study on the Performance Evaluation of the Visual Management Case-base: Development of an Integrated Model by Quantification Theory Category III and AHP", International Journal of Production Research (IJPR), 51(2), 380-394. 
Murata, K. \& Katayama, H., (2010). "Development of Kaizen Case-base for Effective Technology Transfer: A Case of Visual Management Technology", International Journal of Production Research (IJPR), 48(16), 4901-4917.

Ohno, T., Toyota Production System: Beyond Large-Scale Production, Productivity Press, 1988.

Sarhan, S., \& Fox, A. (2013). "Barriers to Implementing Lean Construction in the UK Construction Industry", The Built \& Human Environment Review, 6, 17 pages.

Sarhan, S., Pasquire, C., \& King, A. (2017). "The Concept of Institutional Waste within the Construction Industry: a Potential Theoretical Framework", Lean Construction Journal, 12-24.

Serpell, A., Venturi, A., \& Contreras, J. (1995). Characterization of Waste in Building Construction Projects, Lean construction, 67-77.

Somani, A., \& Minde, P. (2017). Lean Waste Assessment and Blue Print for Elimination Of Waste Through Lean Digital Method, 4(7), 116-120.

Tezel, A., \& Aziz, Z. (2017), "Visual management in highways construction and maintenance in England", Engineering, Construction and Architectural Management, 24(3), 486-513.

Tezel, A., Koskela, L., \& Tzortzopoulos, P. (2016), "Visual management in production management: a literature synthesis", Journal of Manufacturing Technology Management, 27(6), 766-799.

Valente C., Brandalise F., Pivatto M., \& Formoso C. (2017), "Guidelines for Devising and Assessing Visual Management Systems in Construction Sites”, LC3 2017 Volume II - Proceedings of the 25th Annual Conference of the International Group for Lean Construction (IGLC), Walsh, K., Sacks, R., Brilakis, I. (eds.), Heraklion, Greece, 703710. 